\title{
Navassa Island
}

National Cancer Institute

\section{Source}

National Cancer Institute. Navassa Island. NCI Thesaurus. Code C123766.

An island in the Caribbean Sea that is west of Haiti. 